\title{
Inculcating Siri' Na Pacce Value in Primary School Learning
}

\author{
Abdul Azis ${ }^{\bowtie 1}$, Sitti Fithriani Saleh², Ade Irma Suriani² \\ I Sekolah Pascasarjana, Universitas Pendidikan Indonesia, Bandung, Indonesia \\ 2 PGSD FKIP, Universitas Muhammadiyah Makassar, Makassar, Indonesia \\ $\triangle$ abdul.azis@upi.edu
}

\begin{abstract}
Siri' na pacce is the local wisdom of the Bugis-Makassar tribe. Siri' embodies the unification of the attitude of shame and self-esteem, while pacce embodies an attitude of compassion and solidarity. This research aims at describing teachers' perceptions about the inculcation of siri' na pacce value in primary school learning and teaching practices. This research involved 102 primary school teachers in Makassar, Indonesia. The research instruments were questionnaires, interview guidelines, and recorded observations of learning. The majority of participants believed the value of siri' na pacce is still relevant to current conditions and realized their essential role in conveying it to students. Most participants thought that the value of siri' na pacce needs to be integrated into learning, although there were participants who thought it is difficult to do. More than $50 \%$ of participants stated that they always or often conveyed siri' na pacce value to students both inside and outside the classroom. However, less than $50 \%$ of participants regularly or frequently consider how to integrate these values into learning. The activities of integrating siri' na pacce value conducted by the teacher in learning were not well planned yet.
\end{abstract}

Keywords: siri' na pacce, value inculcation, teachers' perceptions, primary school teachers

How to Cite: Azis, A., Saleh, S., \& Suriani, A. (2020). Inculcating Siri' Na Pacce Value in Primary School Learning. Mimbar Sekolah Dasar, 7(1), 82-92 doi:https://doi.org/10.17509/mimbar-sd.v7i1.22461.

INTRODUCTION The culture and characters of the Indonesian people are formed from the diversity of cultures and characters of the region. This diversity enriches the cultural treasury and confirms the identity of the Indonesian's plurality. The culture and character of this nation must continue to be maintained and passed on to the younger generation, so as not to erode the current of globalization. Rencana Pembangunan Jangka Menengah Nasional IV/RPJMN IV (The National Medium Term Development Plan) 2020-2024 deals specifically with the development of the culture and character of the nation.

RPJMN IV emphasized education as an essential pillar of the nation in developing culture and character. Teachers are expected to present a school environment and learning culture that can foster students' habits to behave well (Kementerian PPN/Bappenas, 2019). Likewise, teachers should bring the students closer to the regional cultural roots. An understanding of local wisdom can create pride in national heritage (Hajar \& Ezir, 2018). This pride will be pursed to an increased sense of nationalism. Educational efforts in the school environment must undoubtedly work together with education in the family and the social system. 
Abdul Azis, Sitti Fithriani Saleh, Ade Irma Suriani, Inculcating Siri' Na Pacce ...

Siri' na pacce as the local wisdom of the Bugis-Makassar tribe is a central point in maintaining self-esteem, so someone is still considered tau (human). Siri' embodies the unification of the attitude of shame and self-esteem, while pacce embodies an attitude of compassion and solidarity (Mattulada in Marzuki, 1995). Various expressions in both the Bugis and Makassar languages emphasize siri' as a sign that someone can be called a human being. These expressions include sirik tadji nakitau (only because of having siri' then one can be called a human), sirik emitu tariaseng tau, nereko dei sirikta, tania nik tau, rupagaumi a senna (only by siri' we are called humans, if we do not have siri' then it is no longer human but only a scarecrow), naia dee sirikna, de lainna olo olok (if someone does not have siri', then he is no different from animals), siri' mi na to tau, manekko de'ni sirie tau-tau mani/ olo' olo' ni asengna (only because of siri', a person can be called a human, if humans do not have siri', then he is only a person/called an animal) (Moein, A., 1994; Nurnaningsih, 2015). According to Salam (1998), siri' serves as a guide and impetus that contains noble values, self-esteem, social solidarity, and responsibility in the life of the Bugis-Makassar tribe. Marzuki (1995) argued that someone who maintains siri' in himself will hold on to the five akkatenningeng, namely tongeng (truthful), lempuk (straight, honest), getteng (firm on true belief), sipakatau (mutual respect for fellow human beings), mappesona ri dewata sevae (surrender to God Almighty).

Pacce is related to emotional intelligence, including love, sadness, pain, and solidarity (Ali, 2010). Marzuki (1995) explained that pacce is an expression of empathy, sympathy, or social solidarity with the suffering of others. Farid (2017) interpreted pacce as being related to the spirit of self-sacrifice, hard work, and abstinence. Abdullah (in Umar, 2017) revealed that the fundamental thought of siri' na pacce consists of appasitinajang (fairness), getteng (firm stance), reso (hard work), toto iare ga were (destiny or fate), lempu situru adatongeng (honesty and saying right), warani (brave), and siri' iare ga pesse (self-esteem and compassion).

The noble values of siri' na pacce need to be preserved and inherited to the younger generation, especially in South Sulawesi, and introduced as part of Indonesia's cultural wealth. The implementation of siri' na pacce value in learning in schools can be an effort to preserve and inherit. The habit of applying siri' na pacce value can support students to become individuals who are brave, hard-working, honest, tenacious, highly competitive, loyal, careful in facing problems, consistent, independent in life, and trusting in God in making every effort (Kilawati, 2019).

Previous research revealed the integration of local culture in learning (Saliman, 2007; Suastra, 2010; Tandililing, 2013; Baka, Laksana, \& Dhiu, 2018; Ilhami, Riandi, \& Sriyati, 2019). Suastra (2010) analyzed the needs of junior high school students, which was used as a basis in designing Balinese culture-based science learning models. Saliman (2007) sought to apply 
culture-based learning in order to improve student motivation and learning achievement, especially in Office Administration Learning Planning courses. Ilhami, Riandi, \& Sriyati (2019) integrated the local wisdom of Larangan Fish from the Province of West Sumatra in science learning to improve the environmental literacy of junior high school students. Tandililing (2013) developed mathematics learning based on local culture in West Kalimantan (ethnomathematics) in primary schools. Baka, Laksana, \& Dhiu (2018) examined the integration of the local culture of Ngada (East Nusa Tenggara) in thematic material in primary schools.

This research aims at describing teachers' perceptions about the inculcation of siri' na pacce value in learning in primary schools and the learning practices that teachers have done so far. The results of the research can be taken into consideration for developing a series of learning models based on siri' na pacce in primary schools.

\section{METHOD}

This research was conducted in the second semester of the 2018/2019 Academic Year. The data was presented based on the following events in the field. The data was collected in the form of words or sentences obtained from the results of questionnaires, interviews, and classroom observations. Based on those characteristics, this research employed descriptiveexplorative qualitative research (Creswell, 2012).

\section{Participants}

The participants of this research were public primary school teachers in Panakkukang District, Makassar, Indonesia. The questionnaire was distributed to 102 classroom teachers from 13 schools. Among the participants, five were selected purposefully to undergo interviews and classroom observations.

\section{Instruments}

This research used two types of questionnaires, namely The Perception of Inculcation of Siri' Na Pacce Value Questionnaire and The Inculcation of Siri' Na Pacce Value Questionnaire. The Perception of Inculcation of Siri' Na Pacce Value Questionnaire was used to trace the teachers' perceptions about siri' na pacce value, especially in learning. The Inculcation of Siri' Na Pacce Value Questionnaire was used to explore the learning practices of the teachers by integrating siri' na pacce value. Interview guidelines became a reference for the researchers to explore more in-depth information related to teacher learning perceptions and practices. The researcher also used an audio-visual recording tool that was used during interviews and classroom observations. 
Abdul Azis, Sitti Fithriani Saleh, Ade Irma Suriani, Inculcating Siri' Na Pacce ...

\section{Data Analysis}

The data were analyzed in four stages, namely (a) preparing and organizing data, (b) exploring data, (c) presenting findings, and (d) validating the accuracy of findings. The findings were validated using the triangulation. The results obtained from questionnaires, interviews, and observations were compared to corroborating evidence (Creswell, 2012).

\section{RESULTS AND DISCUSSION}

\section{Teachers' Perceptions Regarding the Inculcation of Siri' Na Pacce Value}

The result of the Perception of Inculcation of Siri' Na Pacce Value Questionnaire is presented in Table 1 below.

Table 1. Teachers' Perceptions Regarding Inculcation of Siri' Na Pacce Value

\begin{tabular}{|c|c|c|c|c|c|c|c|c|c|c|c|}
\hline \multirow[t]{2}{*}{ Statement } & \multicolumn{2}{|c|}{$\begin{array}{l}\text { Strongly } \\
\text { Agree }\end{array}$} & \multicolumn{2}{|c|}{ Agree } & \multicolumn{2}{|c|}{$\begin{array}{l}\text { Neither } \\
\text { Agree nor } \\
\text { Disagree }\end{array}$} & \multicolumn{2}{|c|}{ Disagree } & \multicolumn{2}{|c|}{$\begin{array}{l}\text { Strongly } \\
\text { Disagree }\end{array}$} & \multirow[t]{2}{*}{ Total } \\
\hline & $f$ & $\%$ & $f$ & $\%$ & $f$ & $\%$ & $f$ & $\%$ & $f$ & $\%$ & \\
\hline $\begin{array}{l}\text { The value of siri' na pacce } \\
\text { is still relevant to the } \\
\text { current conditions }\end{array}$ & 47 & 46.08 & 48 & 47.06 & 5 & 4.90 & 2 & 1.96 & 0 & 0.00 & 102 \\
\hline $\begin{array}{l}\text { Inculcation of siri' na } \\
\text { pacce value does not } \\
\text { need to be included in the } \\
\text { lesson plan }\end{array}$ & 0 & 0.00 & 13 & 12.75 & 6 & 5.88 & 70 & 68.63 & 13 & 12.75 & 102 \\
\hline $\begin{array}{l}\text { Knowledge of siri' na } \\
\text { pacce can be inserted at } \\
\text { the beginning or end of } \\
\text { learning }\end{array}$ & 26 & 25.49 & 73 & 71.57 & 1 & 0.98 & 1 & 0.98 & 1 & 0.98 & 102 \\
\hline $\begin{array}{l}\text { Inculcation of siri' na } \\
\text { pacce value is difficult to } \\
\text { practice in classroom } \\
\text { learning }\end{array}$ & 1 & 0.98 & 11 & 10.78 & 11 & 10.78 & 67 & 65.69 & 12 & 11.76 & 102 \\
\hline $\begin{array}{l}\text { Inculcation of siri' na } \\
\text { pacce value needs to be } \\
\text { integrated into classroom } \\
\text { learning }\end{array}$ & 48 & 47.06 & 50 & 49.02 & 3 & 2.94 & 1 & 0.98 & 0 & 0.00 & 102 \\
\hline $\begin{array}{l}\text { The teachers have the role } \\
\text { of conveying the value of } \\
\text { siri' na pacce to students }\end{array}$ & 53 & 51.96 & 46 & 45.10 & 2 & 1.96 & 0 & 0.00 & 1 & 0.98 & 102 \\
\hline $\begin{array}{l}\text { Inculcation of siri' na } \\
\text { pacce value is done in a } \\
\text { family }\end{array}$ & 4 & 3.92 & 7 & 6.86 & 3 & 2.94 & 65 & 63.73 & 23 & 22.55 & 102 \\
\hline
\end{tabular}

Table 1 shows that the majority of teachers who participated in this research believed the value of siri' na pacce is still relevant to current conditions, especially with the effects of globalization and easy access to information on students' attitudes and actions in everyday life. There were only two teachers who thought that the value of siri' na pacce is no longer relevant to the current conditions. The interview results elaborated on the findings of the teachers' belief in which the value of siri' na pacce is still relevant to existing conditions. The 
following statements are opinions of Mal and Asr about the relevance of the value of siri' na pacce with current conditions.

Mal : I think it's still relevant. For example, with YouTube, it is easy for children to access movies containing pornography. If children have siri' value, of course, they will not watch them.

Asr : Siri' or shame and pacce or compassion are at the heart of the culture of the BugisMakassar society. Someone will feel ashamed of God, ashamed of others, ashamed of oneself for committing an offense or doing something that is not good. The value is essential and appropriate to be applied in the current conditions.

There were 83 teachers (81.38\%) who thought that the value of siri' na pacce needs to be included in the lesson plan. Six teachers were still doubtful whether or not the value should be included in the lesson plan, while 13 people thought that it does not need to be included in it. The majority of teachers believed that knowledge of siri' na pacce could be inserted at the beginning or end of learning. Meanwhile, one teacher was hesitant and two people were not sure that knowledge can be added at the beginning or end of learning. In addition, there were $77.45 \%$ of teachers who thought that inculcation of siri' na pacce value was not difficult to practice in classroom learning. $10.78 \%$ of teachers were still doubtful about its practice, while the remaining $11.76 \%$ thought that it is difficult.

Despite the fact, there were still teachers who found difficulties to practice inculcating siri' na pacce values in classroom learning, but the majority of them thought that it needs to be done. There were only three people who doubted and one person who did not agree integrated the inculcation of siri' na pacce value in learning. The following are the opinions of Asr, Ria, and Len when interviewed regarding the integration of siri' na pacce value in learning.

Asr : The value of siri' na pacce needs to be integrated into learning, so children know their distinctive culture and recognize their identity as a Bugis-Makassar tribe. The value of siri' na pacce is encouraging and a pattern of behavior in student life, namely lambusuk (honest), getteng (firm stand), sipakatau (not discriminating), arewang (brave), sipakalebbiri (mutual respect), and sipakainge (mutual reminding).

Ria : The value of siri' na pacce can be integrated into learning as long as it is in line with the syllabus that has been set. The value of siri' na pacce encourages students to be embarrassed if they are not honest, brave, tell the truth, help each other, nor take responsibility.

Len : The value of siri' na pacce can be related to teaching material. I have not included the value in my lesson plan, but when teaching occasionally, I remind students about it.

The teachers were aware of their role in conveying the value of siri' na pacce to students. There were only two people who doubt their position and one person who disagreed. The teachers also realized that the inculcation of siri' na pacce value is not enough to do in the family environment. The schools and community environments also have a responsibility to 
Abdul Azis, Sitti Fithriani Saleh, Ade Irma Suriani, Inculcating Siri' Na Pacce ...

instill these values in students. The following are Len's and Rul's statements regarding this matter.

Len : The family who is introduced first the value of siri' na pacce, but it is important to be cultivated in school, both in the classroom and outside the classroom. It can influence students positively.

Rul: The teachers play the role of conveying the value of siri' na pacce to students. The teachers need to get students used to apply the value of siri' na pacce. For example, when a student is sick, and his friends visit him, I said they have pacce (compassion).

The results of the perception of inculcation of Siri' Na Pacce value questionnaire showed that most of the teachers who participated in this research were aware of the need to instill these values in students in the school environment, including in the learning process. Although, it is still probably somewhat challenging to do. These results were reinforced by the participant statements at the time of the interview.

\section{Learning Activities Accommodates the Inculcation of Siri' Na Pacce Value}

The inculcation of Siri' Na Pacce value questionnaire was given to participants to obtain information about what they had done to instill siri' na pacce values in the school learning. The result of the questionnaire is presented in Table 2.

Table 2. Teachers' Activities to Inculcating The Value of Siri' Na Pacce

\begin{tabular}{|c|c|c|c|c|c|c|c|c|c|c|c|}
\hline \multirow{2}{*}{ Statement } & \multicolumn{2}{|c|}{ Always } & \multicolumn{2}{|c|}{ Often } & \multicolumn{2}{|c|}{ Sometimes } & \multicolumn{2}{|c|}{ Seldom } & \multicolumn{2}{|c|}{ Never } & \multirow{2}{*}{ Total } \\
\hline & $f$ & $\%$ & $f$ & $\%$ & $f$ & $\%$ & $f$ & $\%$ & $f$ & $\%$ & \\
\hline $\begin{array}{l}\text { I include the value of siri' } \\
\text { na pacce in my lesson } \\
\text { plan }\end{array}$ & 17 & 16.67 & 39 & 38.24 & 28 & 27.45 & 14 & 13.73 & 4 & 3.92 & 102 \\
\hline $\begin{array}{l}\text { I remind my students of the } \\
\text { value of siri' na pacce at } \\
\text { the beginning of learning }\end{array}$ & 21 & 20.59 & 37 & 36.27 & 29 & 28.43 & 13 & 12.75 & 2 & 1.96 & 102 \\
\hline $\begin{array}{l}\text { I associate the subject } \\
\text { matter with the value of } \\
\text { siri' na pacce }\end{array}$ & 28 & 27.45 & 27 & 26.47 & 32 & 31.37 & 13 & 12.75 & 2 & 1.96 & 102 \\
\hline $\begin{array}{l}\text { I implement the value of } \\
\text { siri' na pacce in the } \\
\text { learning process }\end{array}$ & 11 & 10.78 & 42 & 41.18 & 38 & 37.25 & 9 & 8.82 & 2 & 1.96 & 102 \\
\hline $\begin{array}{l}\text { I remind students of the } \\
\text { value of siri' na pacce at } \\
\text { the end of learning }\end{array}$ & 21 & 20.59 & 29 & 28.43 & 42 & 41.18 & 10 & 9.80 & 0 & 0.00 & 102 \\
\hline $\begin{array}{l}\text { I apply the value of siri' na } \\
\text { pacce to student activities } \\
\text { outside the classroom }\end{array}$ & 19 & 18.63 & 41 & 40.20 & 30 & 29.41 & 8 & 7.84 & 4 & 3.92 & 102 \\
\hline $\begin{array}{l}\text { I consider how to integrate } \\
\text { the value of siri' na pacce } \\
\text { in learning }\end{array}$ & 11 & 10.78 & 31 & 30.39 & 39 & 38.24 & 13 & 12.75 & 8 & 7.84 & 102 \\
\hline
\end{tabular}

Based on the results of the questionnaire revealed that there were 56 teachers who always or often included the value of siri' na pacce in their lesson plans (54.91\%). While, there were 58 
teachers who always or often reminded students about the value of siri' na pacce at the beginning of learning (56.86\%), and 50 teachers who reminded it at the end of learning (49.02\%). Whereas, there were 55 teachers who always or often associated the subject matter with the value of siri' na pacce $(53.92 \%)$, and 53 teachers stated that they always or often implemented siri' na pacce value in the learning process carried out in the classroom (51.96\%). Moreover, there were 60 teachers who always or often applied the value of siri' na pacce to student activities outside the classroom (58.83), and 42 teachers who always or often considered how to integrate the value of siri' na pacce in learning (41.17\%).

The results of this questionnaire were supported by the results of observing the learning activities conducted by the teachers. The following descriptions outline some examples of teachers' activities to instill the value of siri' na pacce.

\section{Activities Before Entering the Classroom}

Teachers and students had agreed on the actions before entering the classroom. Every morning, the students would line up in front of the classroom, and the teacher checked students' cleanliness and neatness on nails, teeth, hair, and clothes. The teacher carried out the task of examining each student, and the students carried out their obligations to appear clean and neat. It reflected the value of sipakatau (mutual respect) included in siri'. The students feel siri'-siri' (embarrassed) for their dirty appearance. Figure 1 depicts the cleanliness and neatness checking the activity of students in Mrs. Mal's classroom.

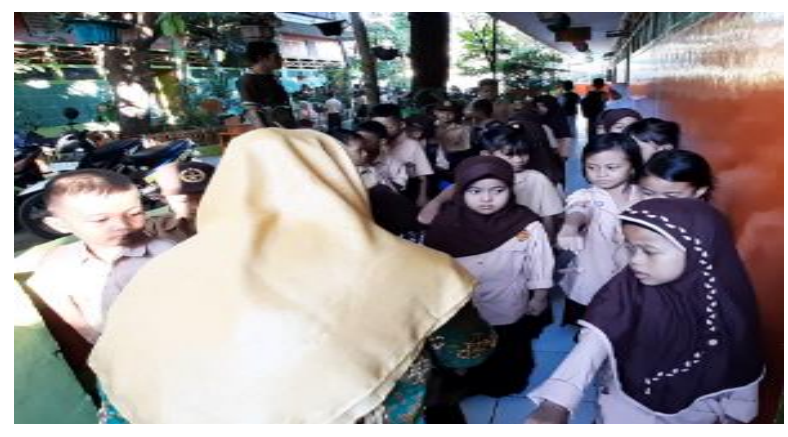

Figure 1. The Cleanliness and Neatness Checking Activity

In the classroom, the students led by the class leader prayed before the class activity began. They asked God to get ease and success in learning. This activity was the embodiment of mappesona ri dewata sevae (surrender to God Almighty), which was one of the five akkatenningeng owned by someone who maintains siri' in himself (Marzuki, 1995). The pappaseng mentioned: Nakana Tupanritaya: teako assalaknu rannuang, pangngapettainna Allahu Ta'ala rannuang, na antu na piagangia- Allahu Ta'ala pangapettai gava bajika (Clerics said: do not rely on the origin of your descendants, but the grace of Allah is 
Abdul Azis, Sitti Fithriani Saleh, Ade Irma Suriani, Inculcating Siri' Na Pacce ...

what you always expect, the grace of God will lead to good deeds) (Mathes in Abbas, 2014). Figure 2 depicts the prayer before the class activity begins in Mr. Asr's classroom.

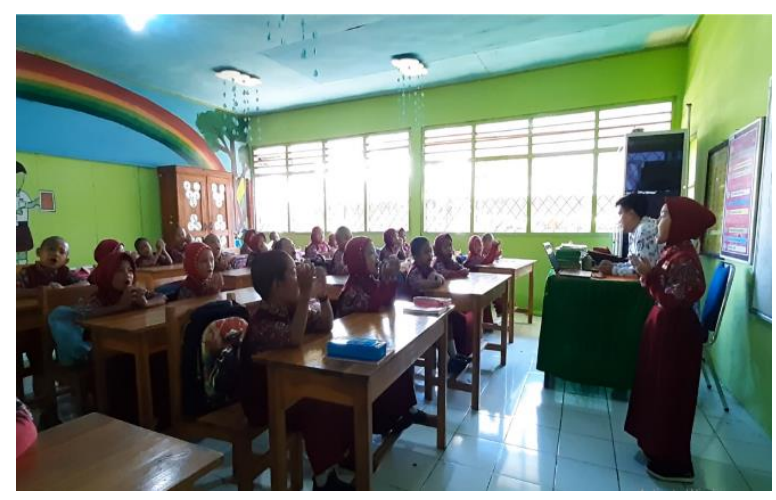

Figure 2. The Prayer Before Class Activity

\section{Teaching and Learning Activities In Classroom}

During observations in Mr. Rul's classroom, the teacher occasionally revealed the value of siri' na pacce. For example, Mr. Rul reminded students to work hard, not cheat the work of friends, or disturb friends. He told students, "siri'-siri' ki (we feel ashamed) if friends can complete the task while you cannot", "siri'-siri' ki (we feel ashamed) to cheat". During group work, he reminded students to work together and help each other in completing group assignments.

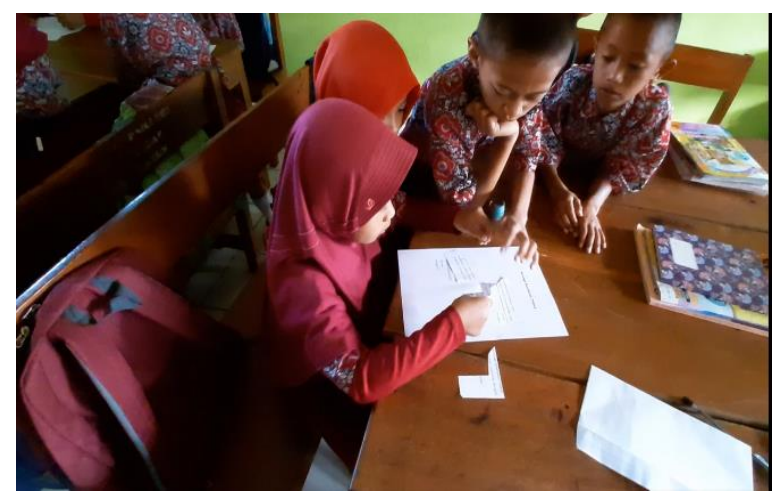

Figure 3. The Group Activity

Figure 3 depicts the example of students' cooperation in doing group work. Students in groups tried to arrange the pieces of the picture into a complete picture. Afterward, they interpreted and explained it to other groups. This activity was a manifestation of reso (hard work). In the pappaseng (message), it was revealed: "Akbulo sibatang pakik, na mareso tamatappuk, na look sannang la ni pusakai" (Only with unity and hard work, happiness can be achieved) (Saleh, 2017). The pappaseng emphasized the importance of uniting, working together, and making serious efforts to achieve worthy goals. 
The pappaseng revealed Lima passaleng namulolongengdecengnge: seuani, pakatunai alemu risitinajannae; maduanna, soroko mase ri sillalennae; matellunna, makkareso patujue; maeppaqna, molae roppo-roppo nareweq; malimanna, molae laleng namatikeq (There are five aspects to consider if you want to get kindness, namely: first, be humble deservedly; second, help others properly; third, do useful work; fourth, face obstacles, truthful in God; fifth, walk carefully) (Hakim in Abbas, 2014). The pappaseng implied that in cooperation, humility is needed by mutual acceptance, mutual assistance in completing useful work, ready to face obstacles by always remembering Allah Almighty, and being careful in solving problems, even if it is complicated. Another pappaseng states rebba sipatokkong, mali siparappeq, siruiq menereq tesiruiq noq, malilu sipakaingeq maingeq pi napaja (when falling, upholding each other, when sinking, stranding each other; pulling each other up and not pressing down on each other; if you forget, remind each other, then wake up or help, then stop) (Sikki in Abbas, 2014). Pappaseng implies that every human being needs to help each other and to remind each other if they make a mistake. Humans should avoid badmouthing one another. The message can be fostered or instilled to students so that they grow up in a culture of working together in completing a given task, and do not complain in the face of severe problems by always solving it together without babbling each other among friends.

\section{Activities Outside the Classroom}

The good behaviors of students need to get teachers' reinforcement. Figure 4 shows students who shared food with their friends at break time. This behavior is an example of applying pacce values. Additionally, extracurricular activities such as scouts, art studios, and dokcil (dokter kecil/little doctors) can be a means to instill the value of siri' na pacce outside the classroom.

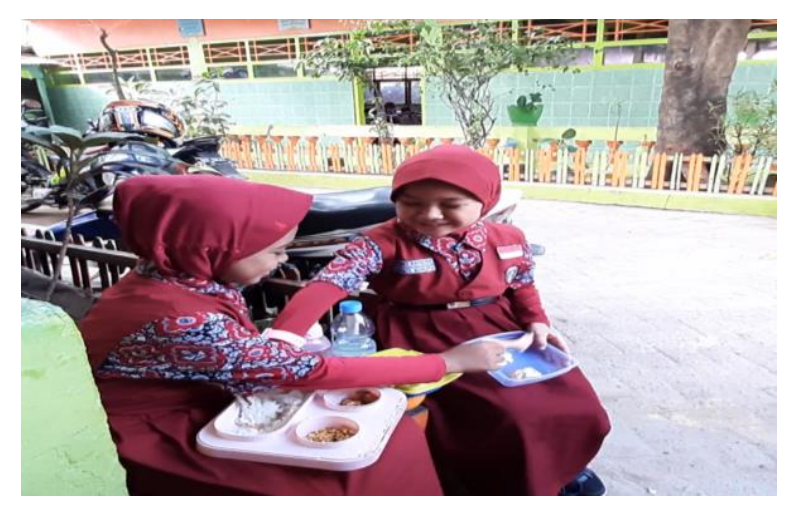

Figure 4. Sharing Lunch

\section{CONCLUSION}

The majority of participants in this research thought that the value of siri' na pacce needs to be integrated into learning. The teachers play an essential role in instilling this value in 
Abdul Azis, Sitti Fithriani Saleh, Ade Irma Suriani, Inculcating Siri' Na Pacce ...

students. Through instilling this value, the local wisdom of the Bugis-Makassar tribe can be preserved and inherited. It can also foster the good characters of students. Some teachers have implemented siri' na pacce values in their learning activities, but these activities were spontaneous and had not been well planned. This indicates the need to develop a learning model that integrates the value of siri' na pacce in learning.

\section{REFERENCES}

Abbas, I. (2014). Etnopedagogik etnik Bugis Makassar: Studi penelusuran nilai-nilai pedagogik pada naskah Lontaraq sebagai pengembangan bahan ajar Pendidikan IPS di sekolah [Ethnopedagogic ethnic Bugis Makassar: Study of tracking pedagogical values in the Lontaraq manuscript as a development of social science education teaching materials in schools]. (Doctoral Dissertation). Universitas Pendidikan Indonesia, Bandung.

Ali, M. (2010). Kelong dalam perspektif hermeneutika [Kelong in the hermeneutic perspective]. Bahasa dan Seni: Jurnal Bahasa, Sastra, Seni, dan Pengajarannya, 38(1). http://journal2.um.ac.id.

Baka, N. A., Laksana, D. N. L., \& Dhiu, K. D. (2018). Konten dan konteks budaya lokal Ngada sebagai bahan ajar tematik di sekolah dasar [Content and context of Ngada local culture as thematic teaching material in elementary schools]. Journal of Education Technology, 2(2), 46-55. DOI: 10.23887/jet.v2i2.16181

Creswell, J., W. (2012). Educational research: Planning, conducting, and evaluating quantitative and qualitative research $\left(4^{\text {th }}\right.$ ed). Boston: Pearson Education Inc.

Farid, Z. A. (2017). Siri', pesse', were' pandangan hidup orang Bugis [Siri', pesse', were' Buginese way of life]. In Hamid, A., et. al. (Ed.). Siri: filosofis suku Bugis, Makassar, Toraja, Mandar (p. 15-64). Makassar: Arus Timur.

Hajar, I., \& Ezir, E. (2018). Integrating social capital and local wisdom in education curriculum designing. In The $11^{\text {th }}$ International Workshop and Conference of ASEAN Studies in Linguistics, Islamic and Arabic Education, Social Sciences and Educational Technology, Malaysia. DOI: 10.31227/osf.io/p2ezw.

Ilhami, A., Riandi, R., \& Sriyati, S. (2019). Implementation of science learning with local wisdom approach toward environmental literacy. In Journal of Physics: Conference Series (Vol. 1157 , No. 2 p. 022030). IOP Publishing. doi:10.1088/1742-6596/1157/2/022030.

Kementerian PPN/ Bappenas. (2019). Rancangan Teknokratik Rencana Pembangunan Jangka Menengah Nasional 2020-2024: Indonesia Berpenghasilan Menengah - Tinggi yang Sejahtera, Adil, dan Berkesinambungan [Technocratic Draft National MediumTerm Development Plan 2020-2024: Prosperous, Fair, and Sustainable Middle-HighIncome Indonesia]. Jakarta: Kementerian PPN/ Bappenas.

Kilawati, A. (2019). Pendidikan karakter dalam budaya siri' na pesse mahasiswa PGSD Universitas Cokroaminoto Palopo [Character education in the culture of siri' na pesse prospective elementary school teachers at Cokroaminoto Palopo University]. Jurnal IImiah Pendidikan Guru SD, 3 (1). DOI: 10.31326/jipgsd.v3i1.287.

Marzuki, M., L. (1995). Siri': Bagian kesadaran hukum rakyat Bugis-Makassar: Sebuah telaah filsafat hukum [Siri': Bugis-Makassar people's legal awareness section: An examination of legal philosophy]. Ujung Pandang: Hasanuddin University Press.

Moein, MG, A. (1994). Menggali nilai-nilai budaya Bugis-Makassar [Exploring Bugis-Makassar cultural values]. Ujung Pandang: Yayasan Makassar Press. 
Nurnaningsih, N. (2015). Rekonstruksi falsafah Bugis dalam pembinaan karakter: Kajian naskah Paseng Toriolo Tellumpoccoe [Reconstruction of Bugis philosophy in character building: Study of Paseng Toriolo Tellumpoccoe manuscript]. Jurnal Lektur Keagamaan, 13(2), 393-416. DOI: 10.31291/jk.v13i2.232.

Salam, A. (1998). Konsepsi dan sosialisasi siri' na pacce masyarakat Bugis (Kasus pada beberapa keluarga Bugis Bone di Sulawesi Selatan) [Conception and socialization of siri' na pacce of Bugis community (Case in several Bugis Bone families in South Sulawesi)]. Doctoral Dissertation, Universitas Padjajaran, Bandung.

Saleh. N, A. (2017). Nilai-Nilai Budaya dalam Pappaseng Tu Riolo [Cultural Values in Pappaseng TU Riolo]. https://kebudayaan.kemdikbud.go.id/bpnbsulsel/nilai-nilaibudaya-dalam-pappasang-tu-riolo/. Accessed on February 20 th 2020.

Saliman (2007, Agustus). Penerapan pembelajaran berbasis budaya sebagai upaya peningkatan kualitas pembelajaran pada mata kuliah Perencanaan Pembelajaran [The implementation of culture-based learning as an effort to improve the quality of learning in Learning Planning courses]. Paper presented in Seminar Nasional Inovasi Pembelajaran, Jakarta.

Suastra, I. W. (2010). Model pembelajaran sains berbasis budaya lokal untuk mengembangkan kompetensi dasar sains dan nilai kearifan lokal di SMP [Local culturebased science learning model for developing basic science competencies and local wisdom values in junior high school]. Jurnal Pendidikan dan Pengajaran, 43 (2), 8-16.

Tandililing, E. (2013, November). Pengembangan pembelajaran matematika sekolah dengan pendekatan etnomatematika berbasis budaya lokal sebagai upaya untuk meningkatkan kualitas pembelajaran matematika di sekolah [Development of school mathematics learning with a local culture-based ethnomathematics approach as an effort to improve the quality of mathematics learning in schools]. In Proceeding Seminar Nasional Matematika dan Pendidikan Matematika, Yogyakarta.

Umar, N. F. (2017). Pengembangan model kepribadian konselor efektif berbasis budaya siri' na pesse [Development of effective counselor personality models based on siri' na pesse culture]. Indonesian Journal of Educational Studies, 20(1). DOI: 10.26858/ijes.v20i1.4425. 